\title{
Adaptation of perennial triticeae to the eastern Central Great Plains
}

\author{
KENNETH P. VOGEL* AND KEVIN J. JENSEN
}

Authors are Research Geneticist, USDA-ARS, 344 Keim Hall, University of Nebraska, P.O. Box 830937, Lincoln, Nebraska 58583-0937 and Research Geneticist, USDA-ARS, Forage and Range Research Laboratory, Utah State University, Logan, Utah 84322-6300. *Corresponding author, kpv@unlserve.unl.edu.

\begin{abstract}
The tribe Triticeae contains over 250 perennial species that are components of grasslands in the temperate and sub-arctic regions of the world and includes some of the world's most valuable forage and rangeland species. Many of these species had not been evaluated previously in the Central Great Plains, USA. A subset of the germplasm of the tribe Triticeae which included over 100 accessions of 55 different species was evaluated in a replicated, space-planted trial in eastern Nebraska during 1994-1996 to determine the survival and forage productivity of the accessions. The evaluated accessions were representative of perennial Triticeae genera and genomes. Perennial grasses of the Triticeae are based on the P, St, H, Ns, E, W, Y genomes and an unknown Xm genome(s). Triticeae that survived and had acceptable forage yields during the period of the trial were the Agropyron's - crested wheatgrasses ( PP and PPPP genomes), Psathyrostachys- Russian wildryes (NsNs genomes), Thinopyron's-intermediate and tall wheatgrasses (EEEEStSt and EEEEEEStSt genomes), some Elymus (StStHH genomes), several Leymus (NsNsXmXm genomes), and Pascopyrum-western wheatgrass (StStHHNsNsXmXm genomes). Several Leymus species had not been evaluated previously in this region but showed considerable potential and merit additional evaluation, including $L$. chinensis, $L$. akmolinensi, L. racemosus, L. sabulosus, and L. secalinus. Species with only the $\mathrm{H}$ genome (Hordeum) and $\mathrm{St}$ genome (Pseudoroegneria) were not adapted to the region because of poor survival or low productivity. The study provides an example of how the rapidly emerging field of genomics can have practical applications to grasslands and rangelands.
\end{abstract}

Key Words: Triticeae, Agropyron, Thinopyrum, Elymus, Leymus, Pascopyrum, survival, forage yield

The tribe Triticeae contains over 250 cool-season, perennial species that are components of grasslands in the temperate and sub-arctic regions of the world. Some Triticeae species such as the crested (Agropyron species) and intermediate wheatgrasses (Thinopyrum sp.) are important species for revegetating grasslands and retired cropland in the Central Great Plains. There is an increasing demand for improved cool-season or $\mathrm{C}_{3}$ grasses to provide high quality forage to livestock during spring, fall, and early winter in integrated livestock production systems in the central Great Plains. In this region rangelands, which are composed

Journal Series No. 12175 , Nebraska Agr. Exp. Sta..

Manuscrpt accepted 15 Jan. 2001.

\section{Resumen}

La tribu Triticeae contiene más de 250 especies perennes que son componentes de los pastizales de las regiones templadas y subárticas del mundo e incluyen algunas de las especies forrajeras más valiosas del mundo. Muchas de estas especies no se han evaluadas previamente en las Grandes Planicies Centrales de Estados Unidos. Un subgrupo de germoplasma de la tribu Triticeae, el cual incluyó mas de 100 entradas de 55 especies diferentes, se evaluó en un ensayo repetido en espacio en el este de Nebraska durante 1994 a 1996 para determinar la sobrevivencia y productividad de las entradas evaluadas. Las entradas evaluadas fueron representativas de generos perennes Triticeae y genomas. Los zacates perennes de la tribu Triticeae están basados en los genomas $\mathrm{P}, \mathrm{St}, \mathrm{H}, \mathrm{Ns}, \mathrm{E}, \mathrm{W}, \mathrm{Y}$ y en un genoma(s) desconocido $\mathrm{Xm}$. Los Triticeae que sobrevivieron y tuvieron rendimientos de forraje aceptables durante el período del ensayo fueron: los Agropyron's - "Crested wheatgrasses" (genomas PP y PPPP), Psathyrostachys - "Russian wildryes" (genomas NsNs), Thinopyron's- "Intermediate" and "Tall wheatgrasses" (genomas EEEEStSt y EEEEEEStSt), algunos Elymus (genomas StStHH ), varios Leymus (genomas NsNsXmXm ) y Pascopyrum - "Western wheatgrass" (genomas StStHHNsNsXmXm). Varias especies de Leymus no habían sido previamente evaluadas en esta región, pero mostraron un considerable potencial y merecen una evaluación adicional, incluyendo $L$. chinensis, $L$. akmolinensi, L. racemosus, L. sabulosus y L. secalinus. Especies con solo el genoma H (Hordeum) y el genoma St (Pseudoroegneria) no se adaptaron a la región debido a su pobre sobrevivencia y baja productividad. Este estudio provee un ejemplo de cómo el emergente campo de genómicos puede tener aplicaciones prácticas en los zacatales y pastizales.

primarily of warm-season $\left(\mathrm{C}_{4}\right)$ grasses or seeded warm-season pastures, are used for summer grazing.

In the last 25 years, several germplasm collection expeditions have been made in eastern Europe and Asia to collect grass germplasm, particularly of the Tribe Triticeae. Many of the collections were made in areas which were previously not open for collection. Extensive germplasm collections of Triticeae species currently are available for evaluation. Except for many of the Thinopyrum accessions (primarily intermediate wheatgrasses, $T$. intermedium, and tall wheatgrasses, $T$. ponticum) and some crested wheatgrasses (Agropyron spp) most of these accessions have not been previously evaluated in the Central Great Plains.

The objective of this study was to evaluate species of the perennial Triticeae that may have potential for use in grassland agriculture in the central Great Plains of the USA and to identify specif- 
ic genomes within the Triticeae grasses that are critical for survival and forage productivity in the eastern part of the Central Great Plains.

Previous research summarized by Dewey (1984), Wang et al. (1994), and Asay and Jensen (1996a, 1996b) and others has demonstrated that perennial grasses of the tribe Triticeae are comprised of the genomes P, St, H, Ns, E, W, Y and an $\mathrm{Xm}$ genome of unknown orgin. The cytogenetic definition of genome, i.e, the haploid set of chromosomes of a diploid species (Shultz-Shaffer 1980) will be used in this report. The classification of the Triticeae has been and remains a matter of controversy (Barkworth 1992, Kellogg 1994). For this paper, the genomic classification, which groups species according to genome content (Dewey 1984, Barkworth and Dewey 1985) will be used with the following exceptions. Under the current GRIN classification system, Tzvelev's (1984) treatment of the Triticeae that lumps the genus Thinopyrum and Pseudoroegneria into the enlarged Elytrigia is used. We will follow Dewey's (1984) treatment that recognizes both Thinopyrum and Pseudoroegneria as separate genera. Dewey (1984) indicated that Leymus species and Pascopyrum contain the $\mathrm{J}(=\mathrm{E})$ genome. Subsequent reports (Zhang and Dvorak 1991, Wang and Jensen, 1994) based on molecular genetic and cytogenetic analysis indicate that the $\mathrm{J}$ genome does not occur in Leymus or Pascopyrum. Asay and Jensen (1996a, 1996b) have designated the unknown genome in Leymus and Pascopyrum the Xm or unknown genome following the genome nomenclature system for the Triticeae proposed by Wang et al. (1994). Species classified as Critesion by Barkworth and Dewey (1985) are listed as Hordeum in this report. To simplify reporting, genus and species names with associated authorities of the plant material used in this study are listed in Table 1 along with common names of some of the more widely used grasses.

\section{Materials and Methods}

Grasses used in this study (Table 1) were primarily plant introductions obtained from the U.S. Department of Agriculture's National Plant Germplasm System via the USDA-ARS Forage and Range Research Laboratory at Utah State University, Logan, Ut. where they were identified. These accessions have a PI (for plant introduction) numerical designation and can be obtained from the USDA Plant Germplasm System. The other accessions used in this study are experimental breeding lines maintained by USDA-ARS Laboratory at Logan, Ut. or were released cultivars (designated cv.) obtained by the USDA-ARS grass breeding program at Lincoln, Neb. The accessions used in the study (Table 1) were chosen to represent the autoploid and alloploid combinations that exist within the perennial Triticeae. Many of the species were represented by 2 accessions originating from different areas. Seeds of the genus Australopyrum which are comprised of the $\mathrm{W}$ genome were not available for use in this study. Chromosome numbers of these accessions were determined by the USDA-ARS Forage and Range Laboratory at Logan, Ut. using conventional chromosome counts or at Lincoln, Neb. where they were estimated by flow cytometry estimates of cellular DNA content (Vogel et al. 1999). The genomic constituents of the species are based on previously summarized or reported research by Dewey (1984), Barkworth and Dewey (1985), Zhang and Dvorak (1991), Liu and Wang (1993), Wang and Jensen (1994), Wang et al. (1994), Asay and Jensen (1996a, 1996b), Zhang and Wang (1996), and Zhang et al. (1996).

Seed of these grasses was planted on 23 March 1994 in a greenhouse at Lincoln, Neb. Prior to seeding, seed was wetchilled for 2 weeks at $4.5^{\circ} \mathrm{C}$ to break dormancy. The seeds were planted in supercell cone-tainers or mini-pots $(22 \mathrm{~cm}$ deep, $4 \mathrm{~cm}$ diam.) which contained a mixture of $2: 1: 1$ soil/peat/vermiculite and were thinned to 1 per cone-tainer after emergence. Natural light was used and the greenhouse was maintained at a temperature range of 21 to $27^{\circ} \mathrm{C}$. Seedlings were transplanted into a field nursery the first week of July 1994. The field evaluation nursery was located at the Univ. of Nebraska Agricultural Research and Development Center, Mead, Neb. (41 ${ }^{\circ} 4^{\prime}$ $\mathrm{N}, 96^{\circ} 5^{\prime} \mathrm{W}$ ) which is located about $35 \mathrm{~km}$ west of Omaha, Neb. The soil type was Sharpsburg silty clay loam (silty clay Typic Argiudoll). Plots were single rows of space-transplanted plants on $1.1 \mathrm{~m}$ centers. Previous research evaluating Agropyron, Thinopyrum, and Bromus perennial grass germplasm accessions in the central Great Plains demonstrated that a small number of replicates harvested for more than 1 year provided adequate statistical precision (Lamb et al. 1984, Vogel 1980, 1983, Vogel et al. 1986). The experimental design was a randomized complete block with 2 replicates. Accessions were blocked by genus. Genera, and species and accessions within a genus were randomized within each replicate.

Hand weeding and herbicides were used for weed control. Since some of the species are highly rhizomatous, periodic roto-tilling with a heavy duty roto-tiller was used to keep plants cut back to an area of $0.2 \mathrm{~m}^{2}$. The herbicides metolachlor [2chloro-N-(2-ethyl-6-methyl-phenyl)-N(2-methoxy-1-methylethyl)acetamide] and imazethapyr \{2-[4,5-dihydro-4methyl-4-(1-methylethyl)-5-oxo-1H-imidazol-2-yl]-5-ethyl-3-pyridinecarboxylic acid \} were applied 2 weeks prior to transplanting and in May of 1995 and 1996 at rates of $2 \mathrm{~kg} \mathrm{ha}^{-1}$ and $0.03 \mathrm{~kg} \mathrm{ha}^{-1}$, respectively. The herbicide 2,4-D (2,4dichlorophenoxyacetic acid) was applied in July of 1994 and May of 1996 for broadleaf weed control. Nitrogen fertilizer was not applied the establishment year. In 1995 and 1996, $112 \mathrm{~kg} \mathrm{~N}^{-1}\left(\mathrm{NH}_{4} \mathrm{NO}_{3}\right)$ was applied the last week of April. No other fertilizers were used.

Plots were harvested after flowering with a flail type plot harvester on 15 August 1995 and 11 July 1996 at a height of approximately $10 \mathrm{~cm}$. Harvest was delayed in 1995 because of our unfamiliarity with the plant material. Some accessions produced only limited seed heads and it was difficult to initially ascertain when flowering had occurred. A subsample from each plot was dried in a forced draft oven at $50^{\circ} \mathrm{C}$ to determine dry matter concentration of the harvested forage, which was used to convert fresh weight yields to a dry weight basis. Because some plants did not survive the establishment year or post-establishment years, yields were expressed on a single-plant basis by dividing plot dry weight by the number of plants harvested per plot each year. Number of plants harvested was determined at the time of harvest. Forage yields are expressed as grams/plant on a dry weight basis. Survival percentage was determined as the percentage of plants surviving at the time of the final forage harvest in 1996. A plant was scored as surviving if any green leaf tissue was present.

Analysis of variance procedures were used to assess the statistical significance of variation among genera and accessions within genera using plot means over years (Snedecor and Cochran 1989). The error variances for genera and accessions nested within genera was used to calculate LSD values for each trait where the $F$ tests for genera or accessions were significant at 
Table 1. Mean forage yields and survival percentages for perennial Triticeae species grown at Mead, Nebraska, 1994 to 1996.

\begin{tabular}{|c|c|c|c|c|c|c|}
\hline Species & Genome $^{1}$ & $2 n^{2}$ & $\begin{array}{l}\text { Accession } \\
\text { or } \operatorname{strain}^{3}\end{array}$ & $\begin{array}{l}\text { Forage } \\
\text { yield }\end{array}$ & Survival & Origin $^{4}$ \\
\hline & & & & (g/plant) & $(\%)$ & \\
\hline \multicolumn{7}{|l|}{ Agropyron Gaertner } \\
\hline A. cristatum & PP & 14 & PI 314600 & 68 & 100 & USSR \\
\hline A. cristatum & PP & 14 & cv Ruff & 233 & 100 & USSR \\
\hline A. mongolicum Keng & PP & 14 & PI 406450 & 92 & 100 & USSR \\
\hline A. mongolicum & PP & 14 & PI 499391 & 58 & 100 & PRC \\
\hline A. desertorum & PPPP & 28 & cv Nordan & 208 & 100 & USSR \\
\hline A. desertorum & PPPP & 28 & PI 314057 & 188 & 100 & USSR \\
\hline & \multicolumn{5}{|c|}{ Pseudoroegneria (Nevski) À. Löve } & USSR \\
\hline P. strigosa (M. Bieb) & StSt & 14 & D3778 & 9 & 80 & PRC \\
\hline P. spicata & StSt & 14 & PI 232134 & 15 & 82 & USA \\
\hline P. stipifolia (Czern ex Nevski) & StSt & 14 & PI 440000 & 35 & 89 & USSR \\
\hline P. geniculata (Trin.) À. Löve & StStStSt & 28 & DJ3875 & 9 & 100 & USSR \\
\hline \multicolumn{7}{|l|}{ Hordeum L. } \\
\hline H. bogdanii Wilensky & $\mathrm{HH}$ & 14 & PI 269406 & 44 & 22 & Afganistan \\
\hline Afganistan $H$. bogdanii & $\mathrm{HH}$ & 14 & PI 440413 & 49 & 19 & USSR \\
\hline H. brachyantherum Nevski & $\mathrm{HH}$ & 14 & D3571 & $38^{6}$ & $0^{6}$ & USA \\
\hline $\begin{array}{l}\text { H. brevisubulatum subsp. violaceum } \\
\text { (Boise \& Hofenacker) Tzvelev }\end{array}$ & $\mathrm{HH}$ & 14 & PI 401374 & 31 & 83 & Iran \\
\hline H. brevisubulatum subsp. violaceum & $\mathrm{HH}$ & 14 & PI 531774 & 68 & 83 & USSR \\
\hline H. bulbosum L. & $\mathrm{HH}$ & 14 & PI 318649 & 4 & 66 & Greece \\
\hline H. bulbosum & HHHH & 28 & PI 343189 & 53 & $0^{6}$ & USSR \\
\hline H. californicum Covas \& Stebbins & $\mathrm{HH}$ & 14 & PI 531778 & 20 & 25 & USA \\
\hline \multicolumn{7}{|l|}{ Psathyrostachys Nevski } \\
\hline P. fragilis (Boise) Nevski & NsNs & 14 & PI 343190 & 42 & 72 & Iran \\
\hline P. fragilis & NsNs & 14 & 343192 & 91 & 100 & Iran \\
\hline P. juncea (Fisher) Nevski [Russian wildrye] & NsNs & 14 & PI 406468 & 142 & 95 & USSR \\
\hline P. juncea & NsNs & 14 & PI 531824 & 116 & 100 & PRC \\
\hline P. stoloniformis C.Baden & NsNs & 14 & D2562 & 33 & 100 & PRC \\
\hline P. stoloniformis & NsNs & 14 & D3376 & 53 & 100 & PRC \\
\hline \multicolumn{3}{|l|}{ Thinopyrum À. Löve } & & 10 & 100 & USSR \\
\hline $\begin{array}{l}\text { T. bessarabicum } \\
\text { T. }\end{array}$ & $E^{b} E^{b}$ & $\begin{array}{l}14 \\
14\end{array}$ & AJC305 & 41 & 88 & USSR \\
\hline T. elongatum (Host) D.R. Dewey & $E^{\mathrm{e}} E^{\mathrm{e}}$ & 14 & D3610 & 18 & 100 & Israel \\
\hline T. junceiforme (Löve \& Löve) Ä Löve & $E^{b} E^{b} E^{e} E^{e}$ & 28 & PI 297873 & 15 & 25 & Portugal \\
\hline T. junceiforme & $E^{b} E^{b} E^{e} E^{e}$ & 28 & D3463 & 66 & 64 & France \\
\hline T. caespitosum Liu \& Wang & EEStSt & 28 & PI 531716 & 56 & 79 & USSR \\
\hline T. caespitosum & EEStSt & 28 & Jasska 4 & 34 & 60 & USSR \\
\hline $\begin{array}{l}\text { T. intermedium (Host) Barkw. \& D.R. Dewey } \\
\text { [intermediate wheatgrass] }\end{array}$ & EEEEStSt & 42 & cv Slate & 362 & 100 & USSR \\
\hline $\begin{array}{l}\text { T. intermedium subsp. barbulatum (Schur) Barkw. \& D.R. } \\
\text { Dewey [pubescent intermediate wheatgrass] }\end{array}$ & EEEEStSt & 42 & cv Manska & 309 & 100 & USSR \\
\hline T. ponticum (Podp.) Barkw. \& D.R. Dewey & $\begin{array}{l}\text { EEEEEE- } \\
\text { StStStSt }\end{array}$ & 70 & cv Platte & 417 & 100 & USSR \\
\hline \multicolumn{7}{|l|}{ Elymus L. } \\
\hline E. abolinii (Drob.) Tzvelev & StStYY & 28 & PI 531554 & 63 & $0^{6}$ & PRC \\
\hline E. abolinii & StStYY & 28 & PI 531555 & 47 & 50 & PRC \\
\hline
\end{tabular}

Continued on page 677 


\begin{tabular}{|c|c|c|c|c|c|c|}
\hline Species & Genome $^{1}$ & $2 n^{2}$ & $\begin{array}{l}\text { Accession } \\
\text { or strain }\end{array}$ & $\begin{array}{l}\text { Forage } \\
\text { yield }\end{array}$ & Survival & Origin $^{4}$ \\
\hline & & & & (g/plant) & $(\%)$ & \\
\hline E. ciliaris (Trin.) Tzvelev & StStYY & 28 & PI 531576 & 60 & 94 & USSR \\
\hline E. canadensis L. [Canada wildrye] & StStHH & 28 & PI 531564 & 154 & 100 & USA \\
\hline E. canadensis & $\mathrm{StStHH}$ & 28 & PI 531565 & 321 & 100 & USA \\
\hline E. caninus L.) L. & StStHH & 28 & PI 253290 & 38 & 65 & Yugoslavia \\
\hline E. caninus & StStHH & 28 & PI 439906 & 31 & 50 & USSR \\
\hline E. glaucus Buckley [blue wildrye] & StStHH & 28 & D3261 & 22 & $0^{6}$ & USA \\
\hline E. glaucus & StStHH & 28 & D3268 & 20 & $0^{6}$ & USA \\
\hline $\begin{array}{l}\text { E. lanceolatus (Schribner \& Smith) Gould } \\
\text { [thickspike wheatgrass] }\end{array}$ & $\mathrm{StStHH}$ & $28^{\mathrm{fc}}$ & D3626 & 109 & 100 & Canada \\
\hline E. lanceolatus & StStHH & 28 & D3627 & 46 & 100 & USA \\
\hline E. mutabilis (Drob.) Tzvelev & StStHH & 28 & PI 499449 & 48 & 67 & PRC \\
\hline E. mutabilis & StStHH & 28 & PI 499589 & 24 & 28 & PRC \\
\hline E. sibiricus $L$. & StStHH & $28^{\mathrm{fc}}$ & PI 499613 & 100 & 67 & PRC \\
\hline E. sibiricus & StStHH & $28^{\mathrm{fc}}$ & PI 499616 & 120 & 100 & PRC \\
\hline $\begin{array}{l}\text { E. trachycaulus (Link) Gould ex Shinners } \\
\text { [slender wheatgrass] }\end{array}$ & StStHH & 28 & PI 232168 & 52 & 100 & USA \\
\hline E. trachycaulus & StStHH & 28 & PI 276711 & 125 & 100 & Hungary \\
\hline E. trachycaulus & StStHH & 28 & PI 315368 & 196 & 100 & USSR \\
\hline E. alatavicus (Drob.) À. Löve & StStYYPP & 42 & PI 499475 & 7 & 44 & PRC \\
\hline E. alatavicus & StStYYPP & 42 & PI 531709 & 19 & 42 & USSR \\
\hline E. batalinii (Krasn.) À. Löve & StStYYPP & $42^{\mathrm{fc}}$ & D3700 & 97 & 69 & USSR \\
\hline E. batalinii & StStYYPP & 42 & DJ4137 & 19 & 93 & USSR \\
\hline E. dahuricus Turez ex Griseb. & StStHHYY & 42 & PI 499592 & 122 & 81 & $\mathrm{PRC}$ \\
\hline E. dahuricus & StStHHYY & 42 & PI499593 & 78 & 81 & PRC \\
\hline \multicolumn{7}{|l|}{ Leymus Hochst. } \\
\hline L. akmolinensis (Drob.) Tzvelev & NsNsXmXm & 28 & PI 440306 & 57 & 100 & USSR \\
\hline L. akmolinensis & NsNsXmXm & 28 & PI 531794 & 161 & 94 & USSR \\
\hline L. ambiguus (Vasey \& Schribn.) D.R. Dewey & NsNsXmXm & $28^{\mathrm{fc}}$ & KJ59 & 28 & 92 & USA \\
\hline L. ambiguus & NsNsXmXm & 28 & PI 531796 & 16 & 100 & USA \\
\hline L. chinensis (Trin.) Tzvelev & NsNsXmXm & 28 & PI 499515 & 273 & 100 & PRC \\
\hline L. chinensis & NsNsXmXm & 28 & PI 499518 & 227 & 100 & PRC \\
\hline L. cinereus (Scribn. \& Merv.) À.. Löve [basin wildrye] & $\begin{array}{l}\text { NsNsNsNs- } \\
\text { XmXmXmXm }\end{array}$ & $56^{\mathrm{fc}}$ & D3706 & 65 & 100 & USA \\
\hline L. cinereus & NsNsNsNs- & $56^{\mathrm{fc}}$ & Magnar & 100 & 100 & Canada \\
\hline L. cinereus & NsNsXmXm & $28^{\mathrm{fc}}$ & KJ51 & 66 & 93 & USA \\
\hline L. coreanus (K.B.Jensen\&R.R.-C. Wang) & NsNsXmXm & & PI 531578 & 58 & 67 & USSR \\
\hline L. flavescens (Scribner \& Smith) Pilger & NsNsXmXm & 28 & Has \& Har & 91 & 100 & USA \\
\hline L. racemosus (Lam.) Tzvelev [mammoth wildrye] & NsNsXmXm & 28 & PI 313965 & 44 & 86 & USSR \\
\hline L. racemosus & NsNsXmXm & 28 & PI 531812 & 416 & 100 & USSR \\
\hline L. cf. racemous & NsNsXmXm & 28 & DJ3801 & 294 & 100 & USSR \\
\hline L. racemosus & NsNsXmXm & 28 & PI 108491 & 290 & 95 & USSR \\
\hline L. cf. ramosus (Trin.) Tzvelev & NsNsXmXm & 28 & PI 499654 & 59 & 100 & PRC \\
\hline L. sabulosus (M. Bieb.) Tzvelev & NsNsXmXm & 28 & PI 531813 & 341 & 100 & USSR \\
\hline L. sabulosus & NsNsXmXm & 28 & PI 531814 & 234 & 100 & USSR \\
\hline L. salinus clone (M.E. Jones) À. Löve & $\begin{array}{l}\text { NsNsNsNs- } \\
\text { XmXmXmXm }\end{array}$ & 56 & PI 531816 & 81 & 100 & USA \\
\hline L. secalinus (Georgi) Tzvelev & NsNsXmXm & 28 & PI 499524 & 226 & 100 & PRC \\
\hline L. secalinus & NsNsXmXm & 28 & PI 499528 & 173 & 95 & PRC \\
\hline L. triticoides (Buckl) Pilger [beardless wheatgrass] & NsNsXmXm & 28 & PI531822 & 170 & 100 & USA \\
\hline L. tritcoides & NsNsXmXm & 28 & D2950 & 162 & 100 & USA \\
\hline L. tritcoides & NsNsXmXm & 28 & Asay M-9 & 125 & 100 & USA \\
\hline L. tritcoides & NsNsXmXm & 28 & cv. Shoshone & 86 & 100 & USA \\
\hline \multicolumn{7}{|l|}{ Pascopyrum À. Löve } \\
\hline P. smithii (Rydb.) À. Löve [western wheatgrass] & $\begin{array}{l}\text { StStHHNsNs- } \\
\text { XmXm. }\end{array}$ & 56 & cv. Flintlock & 247 & 100 & USA \\
\hline P. smithii & $\begin{array}{l}\text { StStHHNsNs- } \\
\mathrm{XmXm}\end{array}$ & 56 & cv Barton & 183 & 100 & USA \\
\hline P. smithii & $\begin{array}{l}\text { StStHHNsNs- } \\
-\mathrm{XmXm}\end{array}$ & 56 & cv. Rodan & 274 & 100 & USA \\
\hline F ratio for accessions & & & & $5.3^{* *}$ & $3.6^{* *}$ & \\
\hline LSD 0.05 & & & & 103 & 34 & \\
\hline
\end{tabular}

${ }_{2}^{1}$ Superscript on genome letters refers to a subset of that genome.

${ }_{3}^{2}$ Ploidy level determined by conventional chromosome counts except where superscript fc indicates ploidy level was estimated by flow cytometry.

${ }_{3} \mathrm{PI}$ numbers are accession numbers of the USDA Plant Germplasm system; other accession/strain numbers are from the USDA Triticeae collection at Logan, Utah (K.Jensen).

${ }^{4}$ PRC $=$ Peoples Republic of China, USSR = area occupied by former Soviet Union, USA = United States of America followed by postal abbreviation of indivual states. See Germplasm Information Network (GRIN) at http://www/ars-grin.gov/ for specific accession information.

${ }_{6}$ USA common name is in brackets [ ].

${ }^{6}$ Some accessions produced forage yields in 1995 but did not have any surviving plants at the time when final stands were determined in July of 1996 . Yields are means for 1995 and 1996. 
Table 2. Monthly precipitation and average monthly temperatures at Mead, Neb. for the duration of the study and 30 year means for Lincoln and Omaha, Nebr.

\begin{tabular}{|c|c|c|c|c|c|c|c|c|c|c|c|c|c|}
\hline Year/ location & Jan. & Feb. & Mar. & Apr. & May & Jun. & Jul. & Aug. & Sep. & Oct. & Nov. & Dec. & Annual \\
\hline & $-\ldots$ & $\cdots-$ & -- & $--\cdot-$ & $-\ldots$ & Ionthly & ipitat & $\mathrm{mm})$ & --- & $\ldots$ & $-\ldots$ & $\ldots$ & $\ldots-\ldots$ \\
\hline 1994 & 12 & 6 & 0 & 32 & 36 & 230 & 107 & 43 & 95 & 34 & 62 & 16 & 674 \\
\hline 1995 & 20 & 10 & 62 & 109 & 145 & 33 & 26 & 34 & 63 & 35 & 12 & 9 & 558 \\
\hline 1996 & 130 & 2 & 23 & 82 & 185 & 140 & 37 & 76 & 51 & 17 & 59 & 10 & 694 \\
\hline Omaha & 17 & 20 & 54 & 70 & 111 & 99 & 83 & 82 & 93 & 61 & 34 & 24 & 747 \\
\hline \multirow[t]{2}{*}{ Lincoln } & 14 & 18 & 53 & 70 & 99 & 99 & 81 & 87 & 88 & 54 & 32 & 22 & 717 \\
\hline & - & - - . & - & 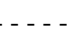 & -- & ge $n$ & tem & ture $(\mathrm{C}$ & - & -- & -- & -- & --- \\
\hline 1994 & -7.2 & -6.7 & 4.7 & 10.1 & 16.9 & 22.4 & 21.7 & 21.6 & 18.3 & 12.6 & 5.1 & -2.6 & 9.7 \\
\hline 1995 & -6.1 & -0.4 & 3.0 & 7.7 & 13.0 & 21.2 & 24.9 & 25.6 & 17 & 11.5 & 0.5 & -2.2 & 9.6 \\
\hline 1996 & -7.8 & -2.7 & -0.6 & 8.5 & 14.3 & 22.1 & 22.2 & 21.6 & 16.4 & 11.9 & -0.4 & -5.9 & 8.3 \\
\hline Omaha & -6.3 & -3.4 & 3.1 & 10.8 & 16.9 & 22.1 & 24.7 & 23.3 & 18.2 & 12.0 & 3.7 & -4.2 & 10.3 \\
\hline Lincoln & -5.9 & -3.0 & -1.9 & 10.9 & 16.7 & 22.4 & 25.6 & 213.8 & 18.5 & 12.0 & 3.8 & -3.6 & 10.4 \\
\hline
\end{tabular}

Data from National Climatic Data Center at http://www.ncdc.noaa/gov.

the 0.05 probability level. Means over years were used because average performance of a perennial over years is the most important indicator of agronomic value, and in previous perennial grass germplasm evaluation research, accession by year interaction effects were either not significant or small (Lamb et al. 1984, Vogel, 1983, Vogel et al. 1986).

\section{Results and Discussion}

In the central Great Plains, the most important trait for a perennial grass is the ability to survive. The temperature of the region can vary from $40^{\circ} \mathrm{C}$ during the summer months to $-40^{\circ} \mathrm{C}$ during winter, sometimes without snow cover (Lawson et al. 1977). During the late fall, winter, and spring there can be large and rapid changes in temperature. Temperature changes of more than $30^{\circ} \mathrm{C}$ can occur within 48 hours. Climatic conditions during this study were typical for the region (Table 2).

Plots were established with transplanted seedlings instead of by direct seeding because of potential differences in seedling vigor and we wanted to ensure that seedlings became well established during the first growing season. There were visible differences among accessions for seedling growth at the time of transplanting. Consequently, we did not collect any first year data but instead used the first growing season to allow the seedlings to become well established. There were significant differences among genera and accessions for survival (Table 1, 3, and 4). As expected based on their previous use in the region, crested wheatgrasses (Agropyron species, P genome) had 100\% survival. Other genera that had species with excellent survival were Pseudoroegneria (St genome), Psathyrostachys (Ns genome) which includes Russian wildrye ( $P$. juncea), Thinopyrum (E and $\mathrm{E}+\mathrm{St}$ genome) species that have both the $\mathrm{E}$ and St genomes (the intermediate and tall wheatgrasses), some Elymus $(\mathrm{St}+\mathrm{Y}, \mathrm{H}$, or $\mathrm{P}$ genomes) species, and most Leymus (Ns+Xm genomes) species. All of the Pascopyrum (St,H,N, and Xm genomes) accessions had survival percentages of $100 \%$. Hordeum (H genome) species had the lowest average survival percentages and no Hordeum species had $100 \%$ survival $($ mean $=34 \%$; range $=0$ to $86 \%$ ). The Pseudoroegneria species with the best survival were from Eurasia while the Elymus species with the best survival were native North American species such as $E$. canadensis, E. lanceolatus, and E. trachycaulus (Table 1). Eighteen of the 24 Leymus accessions had survival percentages of $100 \%$ and only 1 had a survival percentage less than $90 \%$.

The genera with the highest forage yields were Agropyron, Thinopyrum, Leymus, and Pascopyrum (Table 1 and 4). Some species, including Hordeum taxa, had high forage yields the first year of harvest but did not survive the second year. Check cultivars of Agropyrons, Ruff and Nordan, are well adapted standards for identifying species and genomic combinations that had equivalent forage yields $(>$ $100 \mathrm{~g} /$ plant) and more than $90 \%$ survival.

Table 3. Analysis of variance for plant yield and survival of Triticeae species grown at Mead, Nebr. from 1994 to 1996.

\begin{tabular}{lccc}
\hline \hline Source & df & Mean Squares & \\
\hline & & $\frac{\text { Yield (g/plant) }}{29805}$ & $\underline{\text { Survival (\%) }}$ \\
Replicate & 1 & 80124 & 679 \\
Genus & 7 & 2517 & 13407 \\
Replicate x genus & 7 & 14307 & 686 \\
Entry (genus) & 98 & 2695 & 1091 \\
Error & 98 & $31.8^{* *}$ & 301 \\
F for genus & & $5.3^{* *}$ & $19.5^{* *}$ \\
F for species & & $3.6^{* *}$ \\
\hline
\end{tabular}

"*** Indicate significance at the 0.05 and 0.01 levels of probability respectively.
None of the Pseudoroegneria (St genome) or Hordeum (H genome) species had comparable forage yields or survival percentage. The only Psathyrostachys species (Ns genome) that survived both years of the study was Russian wildrye, ( $P$. juncea). The hexaploid and decaploid Thinopyrum species $T$. intermedium and $T$. ponticum had high forage yields and survivability (Table 1). Other genomic combinations within Thinopyrum were not as well adapted. The only Elymus accessions that had yields and survival percentages equivalent to the 2 crested wheatgrass cultivars belonged to species that had the StStHH genomic configuration. These included Canada wildrye (E. canadensis) which is native to Great Plains grasslands, slender wheatgrass (E. trachycaulus) which is native to some North American grasslands, and E. sibiricus, which is an Eurasian counterpart to Canada wildrye. None of the other Eurasian or North American species with the StStHH genomic configuration were as well adapted based on survival scores and forage yields. Many Leymus species with the NsNsXmXm genomic configuration from Eurasia had excellent survival percentages and high forage yields. Many of these species had not been evaluated previously in the Central Great Plains. 
Table 4. Mean forage yields and survival percentages for perennial Triticeae genera averaged over species grown in a space-planted trail at Mead, Nebr. in 1995 and 1996.

\begin{tabular}{lccc}
\hline \hline Genus & Accessions & Forage yield & Survival \\
\hline & $(\mathrm{n})$ & $(\mathrm{g} / \mathrm{plant})$ & $(\%)$ \\
Agropyron & 10 & 153 & 100 \\
Pseudoroegeneria & 10 & 20 & 80 \\
Hordeum & 17 & 57 & 34 \\
Psathyrostachys & 6 & 80 & 94 \\
Thinopyrum & 10 & 153 & 85 \\
Elymus & 24 & 80 & 68 \\
Leymus & 25 & 154 & 97 \\
Pascopyrum & 3 & 235 & 100 \\
F ratio for genera & & $31.8^{* * *}$ & $19.5^{* *}$ \\
LSD & 0.05 & 118 & 44 \\
\hline
\end{tabular}

** Indicates statistical significance at the 0.01 level of probability.

Pascopyrum is a monotypic genus $(P$. smithii - western wheatgrass) that is native to the prairies and plains of North America. The western wheatgrass accessions that were evaluated were representative of Great Plains germplasm and had high forage yields and excellent survival. 'Barton' western wheatgrass was developed by direct increase of a collection from Barton County, Kan., 'Flintlock' was developed by breeding from collection in Kansas and Nebraska, while Rodan was developed by breeding at Mandan, N.D. (Alderson and Sharp 1993)

The adaptability to the central Great Plains and productivity of some of these species such as the crested, intermediate, tall, and western wheatgrasses and Russian wildrye's was known before their genomic configurations were determined (Asay and Jensen 1996a, 1996b). The results of this study correspond with the previously known adaptation and productivity of these species and their constituent genomes. Western wheatgrass apparently gets its adaptability to the central Great Plains from its Leymus genomes (NsNsXmXm). Most species with the HH, HHHH (Hordeum) and StSt, StStStSt (Pseudoroegneria) genomic configurations do not appear to be adapted to the central Great Plains. Several Leymus species showed considerable potential and merit additional evaluation in the central Great Plains. The promising species and the number of accessions of each in the USDA Germplasm System (in parentheses) include Leymus chinensis (36), L. sabulosus (4), L. akmolinensi (3), L. racemosus (30) and L. secalinus (50). In addition to having high forage yields following anthesis, they also had excellent regrowth which stayed green late into the fall. The leaves of some of these species are relatively coarse and their palatability to livestock will need to be determined. According to Asay and Jensen (1996b) many of the Leymus species are characterized by seed dormancy and poor seedling vigor. These traits also will need to be evaluated. In this study, we evaluated only a few of the available accessions of the most promising species. The accessions of these species that are available in the USDA Germplasm System should be evaluated at several locations in the Central Great Plains to identify the most suitable accessions for use in the region and in breeding programs.

The previous work by geneticists such as Douglas Dewey, which has resulted in the genomic characterization of the Triticeae, enabled this study to be structured so that we could characterize grasses by their constituent genomes rather than geographic origin. It provides an example of how the rapidly emerging field of genomics can have practical applications to grasslands and rangelands.

\section{Literature Cited}

Alderson, J.S. and W.C. Sharp. 1993. Grass varieties of the United States. USDA Agr. Handb. 170. Washington, D.C., U.S. Gov. Print. Off.

Asay, K.H. and J.B. Jensen. 1996a. Wheatgrasses. p. 691-724. In: L.E. Moser, D. Buxton, and M.D.Casler (eds.), Cool-season forage grasses. Agron. Monogr.. ASA, CSSA, SSSA, Madison, Wisc.

Asay, K.H. and J.B. Jensen. 1996b. Wildryes. p. 725-748. In: L.E. Moser, D.Buxton, and M.D.Casler (eds.), Cool-season forage grasses. Agron. Monogr. ASA, CSSA, SSSA, Madison, Wisc.

Barkworth, M..E. 1992. Taxonomy of the Triticeae: a historical perspective. Hereditas 116:1-14.

Barkworth, M.E. and D.R. Dewey. 1985. Genomically based genera in the perennial Triticeae of North America: Identification and membership. Amer. J. Bot. 72:767-776.

Dewey, Douglas R. 1984. The genomic system of classification as a guide to intergeneric hybridization with the perennial triticeae $\mathrm{p}$. 209-279. In: J.P. Gustafson (ed.), Gene Manipulation in Plant Improvement. $16^{\text {th }}$
Stadler Genetics Symp., Columbia Mo. Plenum Press, New York, N.Y.

Kellogg, Elizabeth A. 1994. Systematics of the Triticeae: problems and progress, p.207-214. In: R.R.C. Wang, K.B. Jensen, and C. Jaussi (eds.), Proceedings of the $2^{\text {nd }}$ Internat. Triticeae Symp. June 20-24, 1994; Logan, Ut, USA.

Lamb, J. F. S., K. P. Vogel, and P. E. Reece. 1984. Genotype and genotype $x$ environment interaction effects on forage yield and quality of crested wheatgrass. Crop Sci. 24:559-564.

Lawson, Merlin P., Kenneth F. Dewey, and Ralph E. Neild. 1977. Climatic Atlas of Nebraska. Univ. of Nebraska Press, Lincoln, Neb.

Liu, Z-W. and R.R-C. Wang. 1993. Genome analyses of Elytriga caespitosa, Lopopyrum nodosum, Pseudoroegneria geniculata ssp. scythica, and Thinopyrum intermedium. Genome 36:102-111.

Schultz-Shaffer, Jurgen. 1980. Cytogenetics, Plants, Animals, Humans. Springer-Verlag. New York, N.Y.

Snedecor, G.W. and W.C. Cochran. 1989. Statistical Methods. $8^{\text {th }}$ ed. Iowa State Univ. Press. Ames, Ia.

Tzvelev, N.N. 1984. Tribe 3. Triticeae., p. 196-298. A.A. Blakema, Rotterdam.(English translation of: Tzvelev, N.N. 1976. Zlaki SSSR. Nauka Publishers, Leningrad).

Vogel, K. P. 1980. Evaluation of intermediate wheatgrass for use in a breeding program. USDA/SEA-AR, ARR-NC-4. (USDA research bulletin).

Vogel, K. P. 1983. Evaluation of the bromegrass introductions for forage yield and quality. Nebr. Agr. Exp. Sta. Res. Bull. 300.

Vogel, K.P., K. Arumuganathan, and K.B. Jensen. 1999. Nuclear DNA content of perennial grasses of the Tribe Triticeae. Crop Sci. 39:661-667.

Vogel, K.P., P.E. Reece, and J.F.S. Lamb. 1986. Genotype and genotype $\mathrm{x}$ environment interaction effects for forage yield and digestibility of intermediate wheatgrass. Crop Sci. 26:653-658.

Wang, R.R-C and K.B. Jensen. 1994. Absence of the $\mathrm{J}$ genome in Leymus species (Poaceae:Triticeae): Evidence from DNA hybridization and meiotic pairing. Genome 37:231:235

Wang, R.R-C., R. Von Bothmer, J. Dvorak, G. Fedak, I. Linde-Laursen, and $M$. Muramatsu. 1994. P.29-34. In: R.R-C Wang, K.B. Jensen, C. Jaussi (eds.), Proceedings of the $2^{\text {nd }}$ International Triticeae Symposium. Logan, Ut, USA. June 20-24, 1994.

Zhang, H-B. and J. Dvorak. 1991. The genome origins of tetraploid species of Leymus (Poaceae:Triticeae) inferred for variation in repeated nucleotide sequences. Amer. J. Bot. 78: 871-884.

Zhang, W.-Y and R.R-C. Wang. 1996. Genome constitutions of Thinopyrum species determined by RAPD markers and GISH. Agro. Abs. p. 161-162. ASA/CSSA/SSSA, Madison, Wisc.

Zhang, X., Y. Dong, and R.R.-C. Wang. 1996. Characteristics of genomes and chromosomes in partial amphiploids of the hybrid Triticum aestivum $\mathrm{x}$ Thinopyrum ponticum by in situ hybridization, isozyme analyses, and RAPD. Genome 39: 1062-1071. 